\title{
Streambank erodibility and lateral instability hazard in the Manahara River, Kathmandu basin, Nepal
}

\author{
*Pramila Shrestha and Naresh Kazi Tamrakar \\ Central Department of Geology, Tribhuvan University, Kathmandu, Nepal \\ (*Corresponding author: smileprami@hotmail.com)
}

\begin{abstract}
The Manahara River, a large tributary of the Bagmati River, is located in the northeast of the Kathmandu basin. Recently, the river (especially, its lower reach) has been excessively mined for sand and gravel. Such anthropogenic activities together with the natural processes have led to rapid and haphazard shifting of its channel. As a result, its banks and adjacent areas are subject to failures and other mass movements. In this paper, the river course is evaluated in terms of its bank erosion and lateral instability (BELI) hazard by considering bank erodibility hazard index, near-bank stress index, lateral instability hazard index, and anthropogenic disturbances.

The downstream reaches of the fourth-order stream belong to a moderate BELI hazard, whereas the fifth-order stream in the middle reach, near Mulpani, falls under a very high hazard. The rest of its fifth-order stretch exhibits a high hazard. An increase in the degree of anthropogenic disturbances increases the BELI hazard in the downstream stretch of the river. Poor riparian vegetation seems to be one of the factors aggravating the bank erodibility hazard in the river. Hence, the restoration of bank vegetation and establishment of riparian vegetation buffer zones can significantly reduce the BELI hazard.
\end{abstract}

\section{INTRODUCTION}

The systemwide instabilities resulting from the changes in land use and channel modification (by human encroachment or intervention) lead to accelerated streambank erosion, channel shifting, and pollution in a river basin (Leopold and Wolman 1960; Rosgen 1994, 2001). In some rivers, erosion and bank failure produce a significant amount (about $50 \%$ ) of bed load (Rosgen 1976). The Bishnumati River, a tributary of the Bagmati River, has been known for its high bank erodibility hazard and channel instability (Adhikary and Tamrakar 2007). A number of anthropogenic activities are destabilising the banks of this river (Tamrakar 2004).

The Manahara River is one of the major tributaries of the Bagmati River (Fig. 1a) in the Kathmandu basin, which is filled up with fluvio-lacustrine sediments (Sakai 2002). Bajracharya (2006) reported that the Manahara River has shifted its meander belt axis by an average of $143 \mathrm{~m}$ during a period of 11 years.

The Manahara River stretches for $28 \mathrm{~km}$ from northeast to southwest in an elongated basin, and has a high gradient with a short-headed upstream stretch (1st to 3rd order), and a gentle and long downstream course (4th to 5 th order). Its 4th order main stem (i.e. Sali Nadi) extends from Dandakateri to the confluence with the Ghatte Khola. The fifth-order stream initiates from this confluence towards the confluence with the Hanumante River. In this stretch, the river exhibits a sinuous pattern with wide floodplains and is a gravelly to sandy meandering river (Fig. 1b). The northern watershed of the Manahara River lies in the Shivapuri Range, which is composed of gneissic and granitic rocks (Ohta 1973). The eastern and southeastern watersheds are formed of hills composed of quartzites, schists, metasandstones, phyllites, and siltstones (Stöcklin and Bhattarai 1977). The fluviolacustrine sediments of late Pleistocene age border the western and southern low-lying regions of the Manahara River.

The Manahara River has a wide valley and has incised into the fluvio-lacustrine sediments (Bajracharya 1992). Presently, between Kurthali and Sano Thimi, the river is actively wandering in its valley with the deposition of a huge amount of sediments. Several NW-SE trending lineaments and the Manahara Fault crosscut the basin (Bajracharya 1992).

In the Manahara River basin, average monthly rainfall of 447 and $567 \mathrm{~mm}$ was recorded at Changu Narayan and Sankhu, respectively during 1980-2004 (DHM 2005). Heavy precipitation is recorded between June and September with its highest value in July, whereas low rainfall is experienced during November.

\section{River morphology}

The third-order main stem river is straight (sinuosity, $\mathrm{K}=$ 1.09 ) and narrow with an average slope of $0.070 \mathrm{~m} / \mathrm{m}$. Steps, 


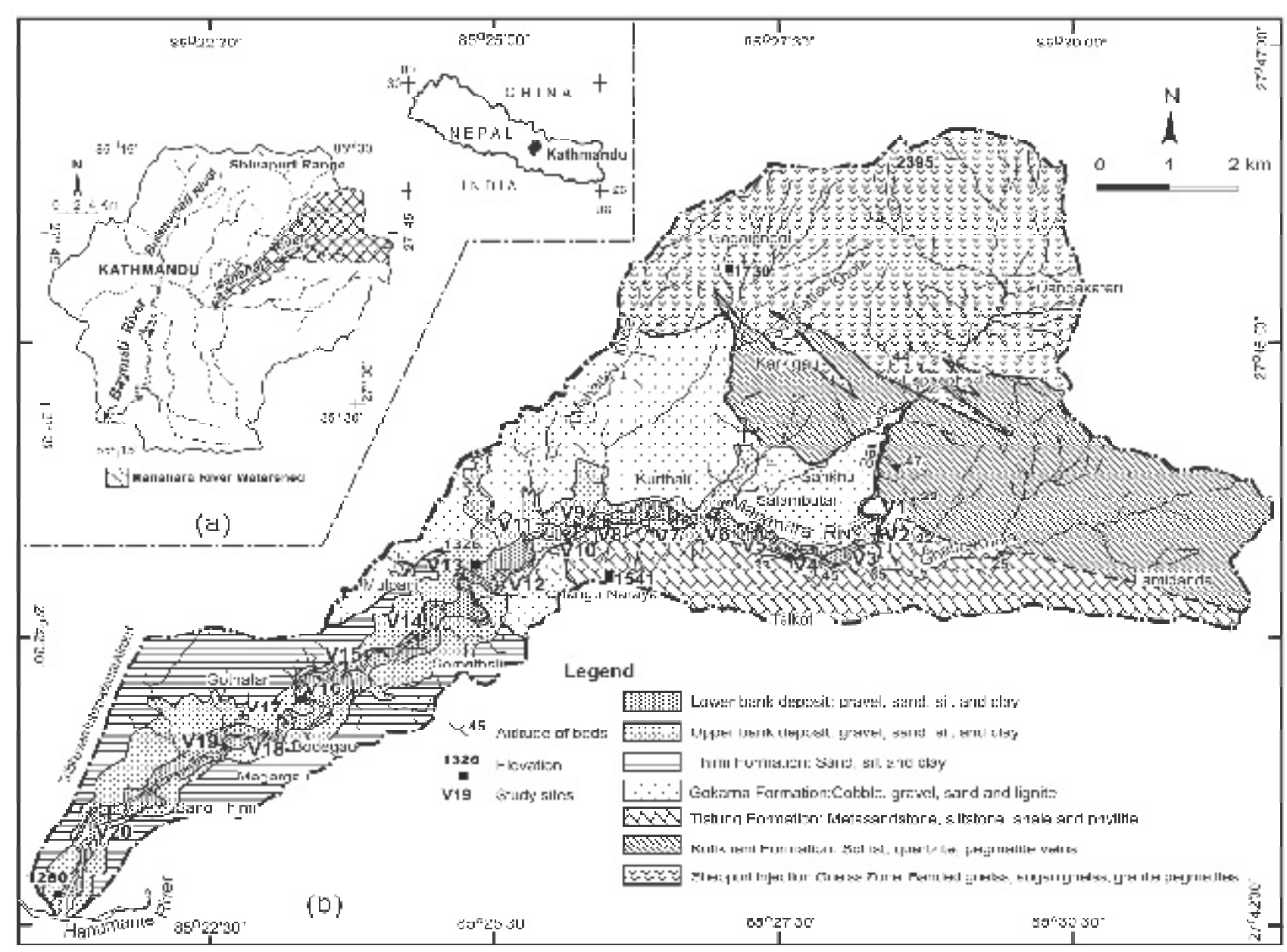

Fig. 1a: Location map of the study area, Fig. 1b: map showing geology and study sites

riffles, and pools contain sediments ranging in size from mega-boulders (>1.5 m) to sand. Point and side bars contain boulders, cobbles, and pebbles with a little (less than $5 \%$ ) sand. The fourth-order main stem river is sinuous $(\mathrm{K}=1.43)$ with a slope of $0.014 \mathrm{~m} / \mathrm{m}$, and has alternating riffles and pools. Its riverbed material is made up of sand, cobbles, and pebbles. Point bars are small containing cobbles, pebbles, and sand with a minor amount of silt, whereas floodplains are narrow.

The upper stretch of the fifth-order stream is meandering $(\mathrm{K}=1.50)$ with riffles and pools, and has a slope of 0.011 $\mathrm{m} / \mathrm{m}$. The riverbed material is composed chiefly of pebbles with a little sand (Fig. 2a). Some mid-channel and side bars contain sand, cobbles, and pebbles. The middle stretch is highly sinuous $(\mathrm{K}=1.81)$, wide, and has many large channel bars. The channel has a very gentle slope of $0.006 \mathrm{~m} / \mathrm{m}$ with riffles and pools. The riverbed material comprises sandy pebbles, whereas bars contain cobbles, pebbles, and sand (Figs. 2b and c). The lower stretch of the main stem river is meandering $(\mathrm{K}=1.52)$ with a gentle slope $(0.023 \mathrm{~m} / \mathrm{m})$, but it is less sinuous as compared to the middle stretch. The riverbanks exhibit erosional scars (Fig. 2d). The riverbed and bar materials comprise pebbly sand. Floodplains are widely developed in the fifth-order stream, and are composed of silt, sand, and gravel.

\section{HAZARD MAPPING IN THE MANAHARA RIVER}

Streambank erosion is a dynamic and natural process, where individual soil particles constituting the bank surface are carried away by the tractive force of flowing water and the magnitude of force generally increases with increasing flow velocity. Rosgen $(1994,1996,2001)$ observed that bank erodibility is a function of (a) its morphology, vegetation, and material, which are incorporated in the bank erodibility hazard index (BEHI), and (b) stream slope, depth, and velocity in near-bank region, which are considered in terms of the near-bank stress index (NBSI). Other factors which aggravate streambank erosion are lateral instability of channel (depending on its width/depth ratio and meander width ratio) expressed in terms of the lateral instability hazard index 

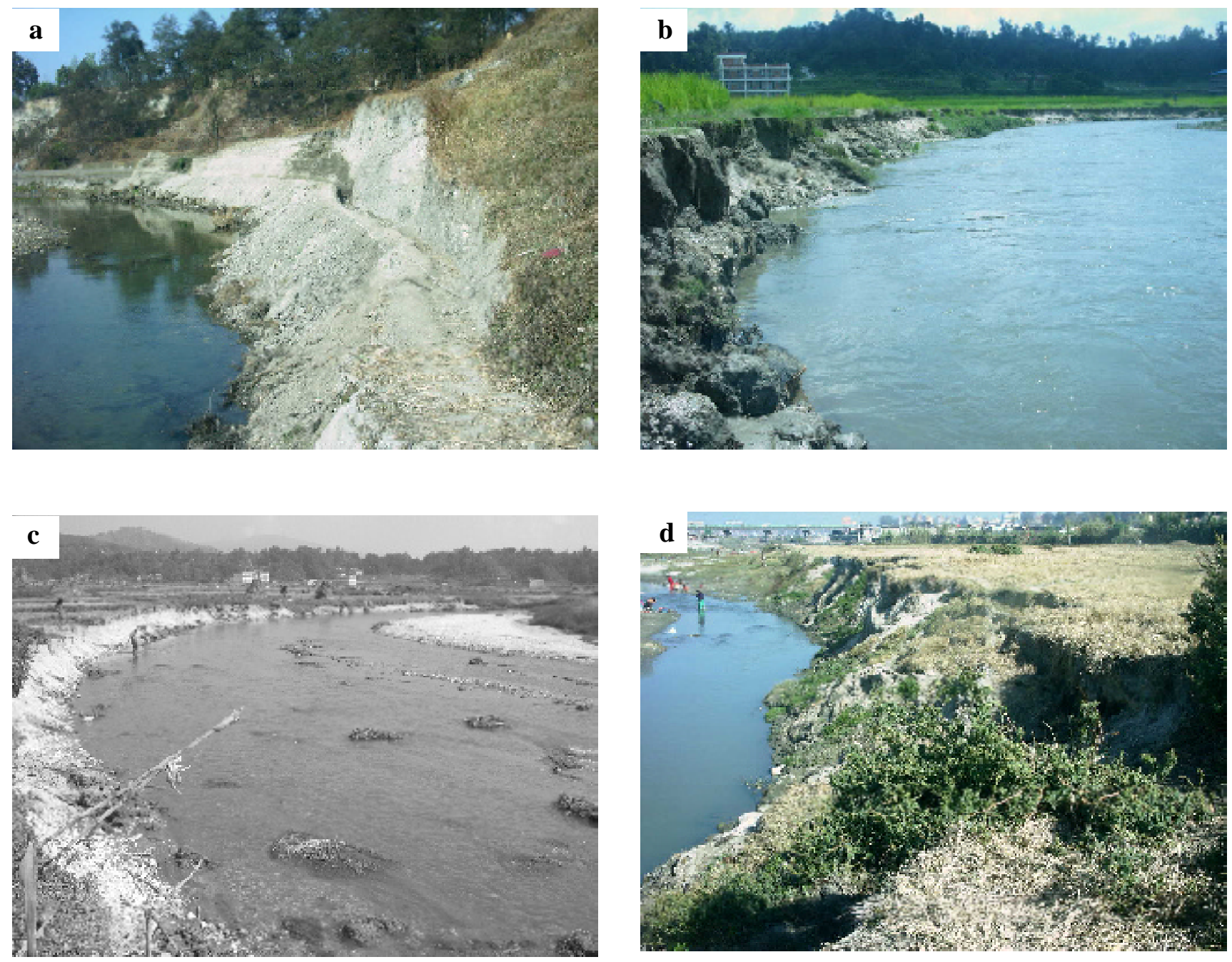

Fig. 2: Photographs showing (a) bank height and material at Salambutar, (b) bank material and its erosion at Mulpani, (c) concave bend of Manahara River at Somathali, and (d) bank failure at Sano Thimi

(LIHI), and anthropogenic disturbance (AD). These parameters were assessed to generate a streambank erosion and lateral instability hazard map of the Manahara River.

For this purpose, twenty locations (Fig. 1b) in the Manahara River were surveyed. The cross-sections and longitudinal profiles measured with a levelling instrument, tape, and staff. At the same time, planiform (sinuosity, meander length ratio, meander width ratio), morphological (width, depth, area), and hydraulic parameters (discharge, velocity, tractive shear stress, stream power) were also determined. Finally, BEHI, NBSI, LIHI, and AD were assessed and their values were transformed into corresponding ratings using Table 1 together with Figs. 3, 4, and 5. The total BELI rating for a given location was then found by adding the corresponding values of the four parameters. After that, it was further classified into very low $(<22)$, low (22-44), moderate (44-66), high (66-88), very high (88-99), and extreme (>99) hazard categories (Table 1).

\section{Bank erodibility hazard index}

Five streambank characteristics were assessed following Rosgen (1996) in the stream widths selected for streambank erosion study. The variables included were 1) bank height ratio $(\mathrm{BHR}=$ streambank height/maximum bankfull depth $)$; 2) ratio of root depth to bank height (RDR); 3) root density (RD); 4) bank angle; and 5) surface protection (Table 2). Using Table 1 and Fig. 3, these streambank variables were transferred to hazard ratings ranging from 1 to 10 corresponding to a very low (VL), low (L), moderate (M), high $(\mathrm{H})$, very high $(\mathrm{VH})$, and extreme (E) BEHI hazards (Table 2). Following Rosgen (1996), apart from above five parameters, bank material type, its stratification, texture, and stiffness were also considered for obtaining BEHI. The BHR, bank angle, and RDR were calculated quantitatively in the field at each location, where the root density and per cent surface area of bank protection were obtained by qualitatively evaluating the vegetation present on banks of each location. 
Table 1: Criteria for evaluating bank erosion and lateral instability hazard levels

\begin{tabular}{|c|c|c|c|c|c|c|c|c|}
\hline \multirow{2}{*}{ Parameters } & \multirow{2}{*}{ Attributes } & \multicolumn{7}{|c|}{ Hazard levels } \\
\hline & & & Very low & Low & Moderate & High & Very high & Extreme \\
\hline \multirow{11}{*}{$\begin{array}{l}\text { *Bank } \\
\text { erosion } \\
\text { hazard } \\
\text { index (BEHI) }\end{array}$} & \multirow{2}{*}{ Bank height ratio } & Value & $1.0-1.1$ & $1.1-1.2$ & $1.2-1.5$ & $1.5-2$ & $2-2.8$ & $>2.8$ \\
\hline & & Index & $1-2$ & $2-4$ & $4-6$ & $6-8$ & $8-9$ & 10 \\
\hline & \multirow{2}{*}{ Root depth ratio $(\%)$} & Value & $100-80$ & $80-55$ & $55-30$ & $30-15$ & $15-5$ & $<5$ \\
\hline & & Index & $1-2$ & $2-4$ & $4-6$ & $6-8$ & $8-9$ & 10 \\
\hline & \multirow{2}{*}{ Root density (\%) } & Value & $100-80$ & $80-55$ & $55-30$ & $30-15$ & $15-5$ & $<5$ \\
\hline & & Index & $1-2$ & $2-4$ & $4-6$ & $6-8$ & $8-9$ & 10 \\
\hline & \multirow{2}{*}{ Bank angle (degrees) } & Value & $0-20$ & $20-60$ & $60-80$ & $80-90$ & $90-120$ & $>120$ \\
\hline & & Index & $1-2$ & $2-4$ & $4-6$ & $6-8$ & $8-9$ & 10 \\
\hline & \multirow{2}{*}{ Surface protection $(\%)$} & Value & $100-90$ & $90-50$ & $50-30$ & $30-15$ & $15-5$ & $<5$ \\
\hline & & Index & $1-2$ & $2-4$ & $4-6$ & $6-8$ & $8-9$ & 10 \\
\hline & Total BEHI & & $<10$ & $10-20$ & $20-30$ & $30-40$ & $40-45$ & $>45$ \\
\hline \multirow{2}{*}{$\begin{array}{l}* * \text { Near bank } \\
\text { stress index (NBSI) }\end{array}$} & \multirow{2}{*}{ Near bank stress index } & Value & $<0.8$ & $0.8-1.05$ & $1.06-1.14$ & $1.15-1.19$ & $1.20-1.60$ & $>1.60$ \\
\hline & & Index & $<2$ & $2-4$ & $4-6$ & $6-8$ & $8-9$ & $>9$ \\
\hline \multirow{9}{*}{$\begin{array}{l}\text { Lateral } \\
\text { instability } \\
\text { hazard } \\
\text { index (LIHI) }\end{array}$} & \multirow{2}{*}{ Sinuosity (K) } & Value & $<1.2$ & $1.2-1.4$ & $1.4-1.6$ & $1.6-1.8$ & $1.8-2.0$ & $>2.0$ \\
\hline & & Index & $1-2$ & $2-4$ & $4-6$ & $6-8$ & $8-9$ & $>9$ \\
\hline & \multirow{2}{*}{ Meander width ratio } & Value & $<2$ & $2-5$ & $5-10$ & $10-15$ & $15-20$ & $>20$ \\
\hline & & Index & $1-2$ & $2-4$ & $4-6$ & $6-8$ & $8-9$ & $>9$ \\
\hline & \multirow{2}{*}{ Meander length ratio } & Value & $<10$ & $10-15$ & $15-20$ & $20-25$ & $25-30$ & $>30$ \\
\hline & & Index & $1-2$ & $2-4$ & $4-6$ & $6-8$ & $8-9$ & $>9$ \\
\hline & \multirow{2}{*}{$\mathrm{W} / \mathrm{D}$ ratio } & Value & $<1.4$ & $1.4-2.0$ & $2.0-10$ & $10-20$ & $20-40$ & $>40$ \\
\hline & & Index & $1-2$ & $2-4$ & $4-6$ & $6-8$ & $8-9$ & $>9$ \\
\hline & Total LIHI & & $<8$ & $8-16$ & $16-24$ & $24-32$ & $32-36$ & $>36$ \\
\hline \multirow{3}{*}{$\begin{array}{l}\text { Anthropogenic } \\
\text { disturbance }\end{array}$} & \multirow{2}{*}{ Percent disturbance } & Value & $<5$ & $5-10$ & $10-15$ & $15-20$ & $20-25$ & $>25 \%$ \\
\hline & & Index & $1-2$ & $2-4$ & $4-6$ & $6-8$ & $8-9$ & $>9$ \\
\hline & Total rating & & $<22$ & $22-44$ & $44-66$ & $66-88$ & $88-99$ & $>99$ \\
\hline
\end{tabular}

* Rosgen (1996): For adjustment in points for specific nature of bank materials and stratification, the following is used: Bank material: Bedrock (very low), Boulder (low), Cobble (Subtract 10 points unless gravel/sand>50\%, then no adjustment), Gravel (add 5-10 points depending on \% sand), Sand (add 10 points), silt/clay (no adjustment) Stratification: points depending on the number and position of layer 5-10 points were added **Categories of Rosgen (2001)

\section{Bank height ratio and bank angle}

Generally, a higher BHR indicates a higher susceptibility to erosion. The slope of streambank is an indicator of its erosion rate. Vertical slopes or cantilever banks generally exhibit high erosion rates. In the Manahara River, streambanks are steep (Fig. 7) at all the locations and fall on a high to very high category of hazard levels (Table 2).

\section{Extent of bank vegetation, RDR, RD, and surface protection}

The riparian vegetation buffer zone (area between channel and flood plain) of the Manahara River includes (a) overstorey (more than $5 \mathrm{~m}$ high tree and bamboo), (b) understorey of more than $1 \mathrm{~m}$ high shrubs, tall grasses and small trees, and (c) ground cover of herbs, grass, bushes, and plant litter. Riparian vegetation buffer is variable in terms of types and extent, and in the third- and fourth-order stretches, it comprises a wide corridor (5-20 m) of mixed overstorey, understorey, and ground cover. In some places, overstorey is discontinuous and leans out but dense understorey and ground cover line up the stream banks. The whole buffer zone leans out from the fifth-order stretch downstream, where overstorey comprises patches, and understorey and ground cover densely distribute in a narrow corridor. Further downstream (south of Mulpani), most of the banks are cultivated where overstorey is rare but the understorey and ground cover exist as a very narrow $(<5 \mathrm{~m})$ corridor. Because of river wandering on cultivated land, no overstorey and understorey could be re-established.

Along the Manahara River, up to the fourth-order stretch in Sankhu, the vegetation is present not only on banks but also beyond them. Overstorey trees forming canopy, understorey trees, shrubs and grasses forming ground cover are present providing high RDR and RD. The extent of vegetation in the 5 th order main stem is very poor (Fig. 7), where shrubs and grasses with very rare trees represent bank vegetation. The extent of bank vegetation, RDR and $\mathrm{RD}$ are very week, which are not enough to support streambanks.

\section{Bank material texture, stratification, and stiffness}

The Manahara River flows over the resistant rock up to the fourth-order stretch where the streambanks are mostly bounded by rocks with sporadic unconsolidated alluvial and colluvial deposits (Figs. 6a, 7). In the fifth-order stretch, the streambanks comprise stratified and unconsolidated cobbles, 

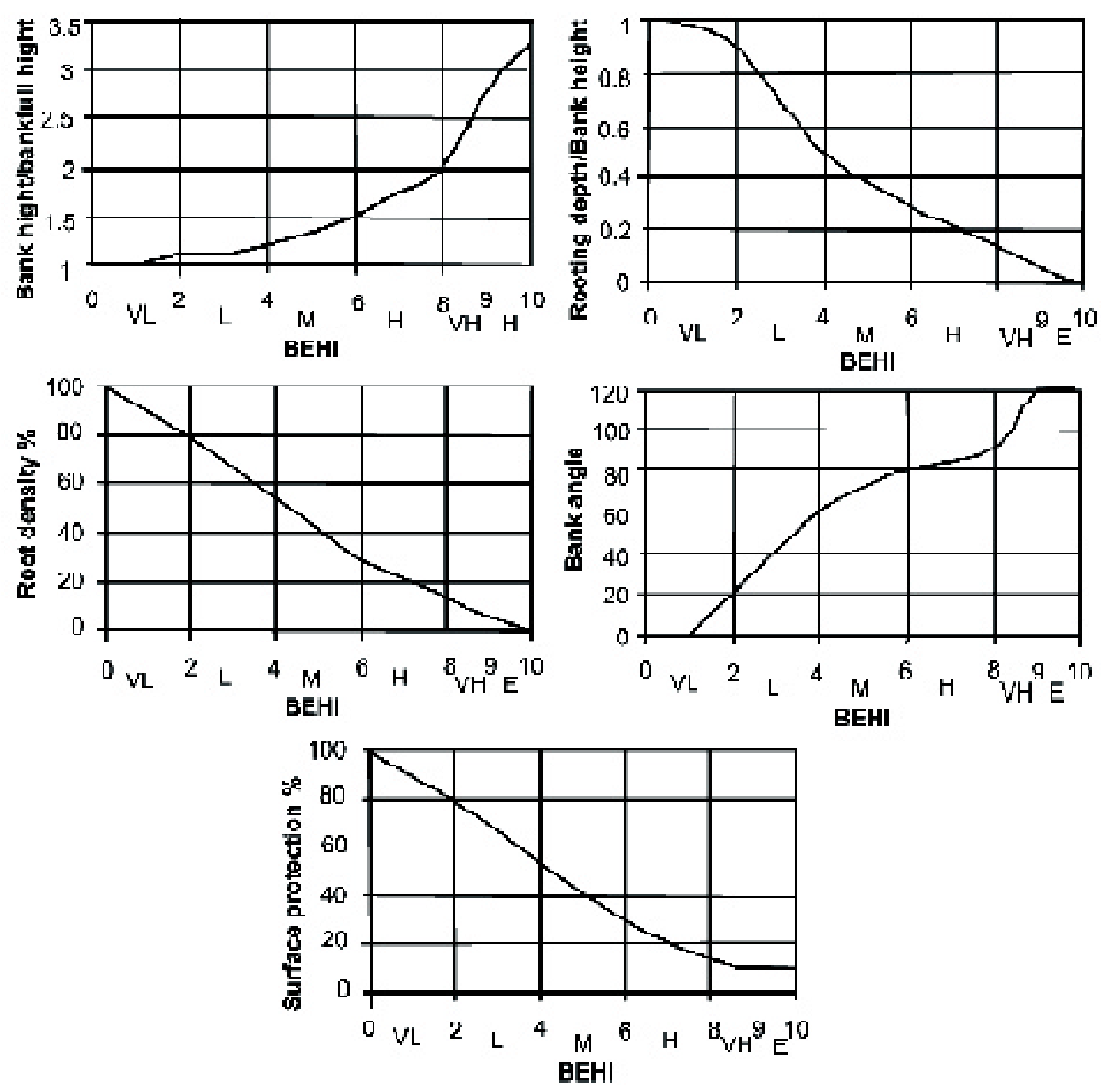

Fig. 3: $\mathrm{BEHI}$ attributes plotted against hazard ratings: $\mathrm{VL}=$ very low, $\mathrm{L}=$ low, $\mathrm{M}=$ moderate, $\mathrm{H}=$ high, $\mathrm{VH}=$ very high, and $\mathrm{E}=$ extreme hazards (after Rosgen 1996)

pebbles, sand, silt, and clay of the basin-fill sediments (Figs. $6 \mathrm{~b}, 6 \mathrm{c}, 7)$. In the downstream stretches, black clay or silt and clay beds underlie sand and gravel. In the Sano Thimi area, silt and sand lamina are dipping at an angle of 40 degrees and on top of them are horizontal sand and gravel beds (Fig. 6d). Except at some locations where bedrock and black cohesive clay are exposed, most of the bank materials are made up of cohesionless sediments (Fig. 7).

\section{Status of bank erodibility hazard}

According to the results (Table 2), upstream locations as V1 and V2 at Sankhu and location V9 (Fig. 1) exhibit the moderate potential of streambank erosion. Locations V5, V7, V11 to V13, and V17 to V19 (Fig.1) bear very high bank erodibility potential. The rest of the study locations indicate high bank erodibility hazard. BEHI does not indicate downstream trend and is probably influenced by the local variation of the parameters assessed. In most of the fifthorder stretches, BEHI is high to very high. Similar results were also obtained from the Bishnumati River ( Tamrakar 2001, Adhikary and Tamrakar 2007).

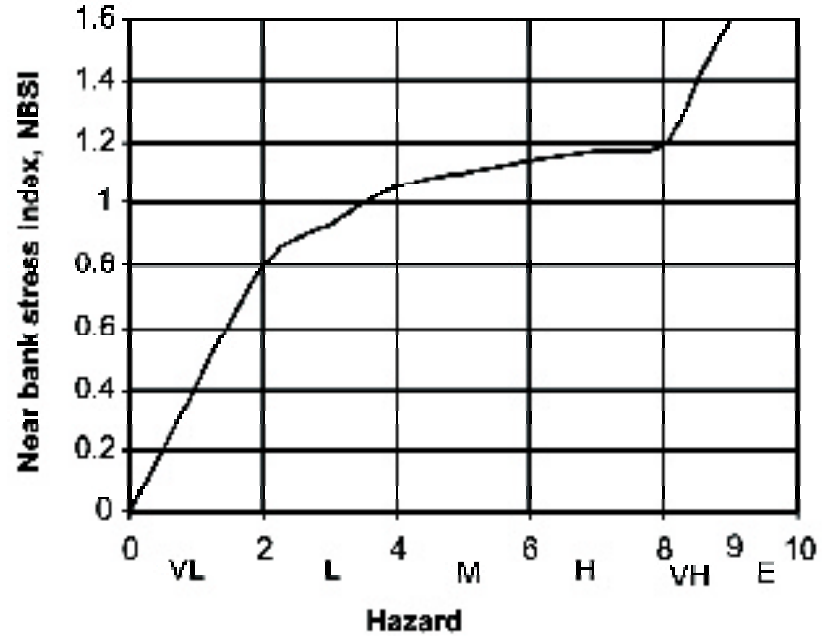

Fig. 4: NBSI attributes plotted against hazard ratings: $\mathrm{VL}=$ very low, $\mathrm{L}=$ low, $\mathrm{M}=$ moderate, $\mathrm{H}=$ high, $\mathrm{VH}=$ very high, and $\mathrm{E}=$ extreme hazards 

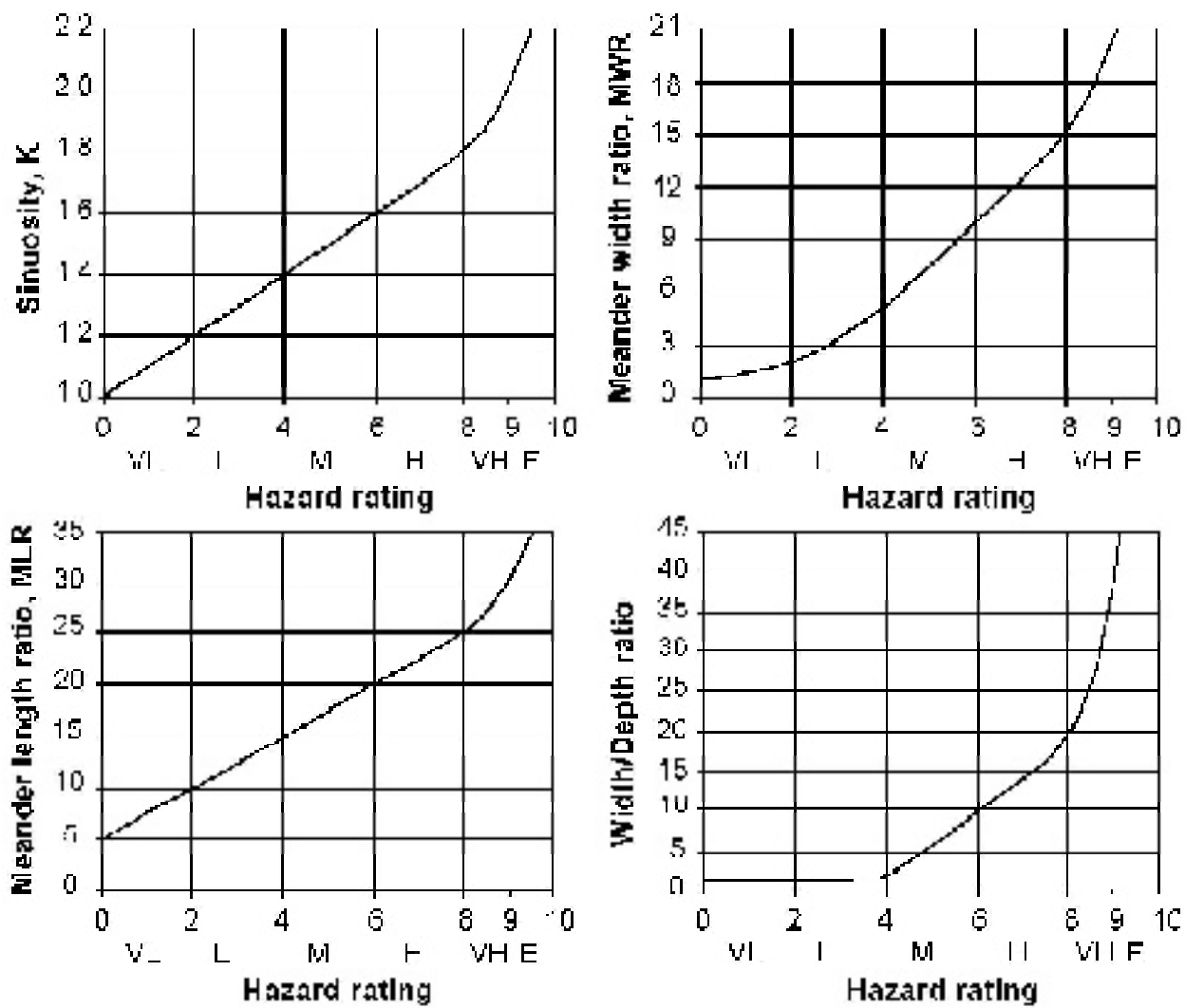

Fig. 5: $\mathrm{LIHI}$ attributes plotted against hazard ratings: $\mathrm{VL}=$ very low, $\mathrm{L}=$ low, $\mathrm{M}=$ moderate, $\mathrm{H}=$ high, $\mathrm{VH}=$ very high, and $\mathrm{E}=$ extreme hazards

Table 2: Field data of BEHI values and their corresponding hazard ratings

\begin{tabular}{|c|c|c|c|c|c|c|c|c|c|c|c|c|}
\hline \multirow[b]{2}{*}{ Location } & \multirow[b]{2}{*}{ Bank } & \multicolumn{5}{|c|}{ Field measured variables } & \multicolumn{6}{|c|}{ Bank erosion hazard index (BEHI) rating } \\
\hline & & $\begin{array}{c}\text { Bank } \\
\text { height } \\
\text { ratio } \\
(\mathbf{m} / \mathbf{m})\end{array}$ & $\begin{array}{c}\text { Root } \\
\text { depth } \\
\text { ratio } \\
(\%)\end{array}$ & $\begin{array}{c}\text { Root } \\
\text { density } \\
(\%)\end{array}$ & $\begin{array}{c}\text { Bank } \\
\text { Angle } \\
\text { (Degrees) }\end{array}$ & $\begin{array}{c}\text { Surface } \\
\text { Protection } \\
(\%)\end{array}$ & $\begin{array}{c}\text { Bank } \\
\text { height } \\
\text { ratio }\end{array}$ & $\begin{array}{l}\text { Root } \\
\text { depth } \\
\text { ratio }\end{array}$ & $\begin{array}{c}\text { Root } \\
\text { density }\end{array}$ & $\begin{array}{l}\text { Bank } \\
\text { Angle }\end{array}$ & $\begin{array}{c}\text { Surface } \\
\text { Protection }\end{array}$ & $\begin{array}{c}\text { Total } \\
\text { adjusted } \\
\text { BEHI }\end{array}$ \\
\hline V1 & left & 1.23 & 75 & 70 & 125 & 50 & 4.5 & 2.8 & 2.8 & 10.0 & 4.0 & $24.1(\mathrm{M})$ \\
\hline $\mathrm{V} 2$ & right & 1.09 & 20 & 40 & 85 & 20 & 1.5 & 7.2 & 5.0 & 7.0 & 7.5 & $28.2(\mathrm{M})$ \\
\hline $\mathrm{V} 3$ & left & 1.04 & 11 & 15 & 90 & 10 & 1.0 & 8.4 & 7.7 & 8.0 & 8.5 & $38.6(\mathrm{H})$ \\
\hline $\mathrm{V} 4$ & left & 1.08 & 33 & 40 & 105 & 20 & 1.5 & 5.3 & 5.0 & 8.5 & 7.5 & $32.8(\mathrm{H})$ \\
\hline $\mathrm{V} 5$ & right & 1.67 & 18 & 20 & 85 & 15 & 6.8 & 7.4 & 7.0 & 7.0 & 8.0 & $41.2(\mathrm{VH})$ \\
\hline V6 & right & 1.07 & 19 & 15 & 90 & 10 & 1.4 & 7.3 & 7.7 & 8.0 & 7.5 & $36.9(\mathrm{H})$ \\
\hline V7 & left & 1.06 & 20 & 20 & 115 & 25 & 1.4 & 7.2 & 7.0 & 8.8 & 6.5 & $40.9(\mathrm{VH})$ \\
\hline V8 & left & 1.13 & 24 & 20 & 85 & 27 & 1.5 & 6.8 & 7.0 & 7.0 & 6.4 & $33.9(\mathrm{H})$ \\
\hline V9 & right & 1.07 & 44 & 35 & 80 & 30 & 1.5 & 4.1 & 5.3 & 6.0 & 6.0 & $27.9(\mathrm{M})$ \\
\hline V10 & left & 1.08 & 29 & 15 & 75 & 20 & 1.6 & 6.0 & 7.7 & 5.5 & 7.5 & $33.3(\mathrm{H})$ \\
\hline V11 & right & 1.09 & 13 & 5 & 125 & 15 & 1.6 & 8.1 & 9.0 & 10.0 & 8.0 & $41.7(\mathrm{VH})$ \\
\hline V12 & right & 1.21 & 29 & 20 & 90 & 20 & 4.0 & 6.0 & 7.0 & 8.0 & 6.5 & $41.5(\mathrm{VH})$ \\
\hline V13 & right & 1.48 & 12 & 15 & 85 & 15 & 5.5 & 8.2 & 7.7 & 7.0 & 8.0 & $46.4(\mathrm{VH})$ \\
\hline V14 & left & 1.08 & 54 & 17 & 90 & 25 & 1.6 & 4.0 & 7.6 & 8.0 & 6.5 & $32.7(\mathrm{H})$ \\
\hline V15 & left & 1.17 & 21 & 15 & 90 & 20 & 3.8 & 7.2 & 7.7 & 8.0 & 7.5 & $39.2(\mathrm{H})$ \\
\hline V16 & right & 1.11 & 32 & 15 & 90 & 10 & 2.0 & 5.9 & 7.7 & 8.0 & 7.0 & $35.6(\mathrm{H})$ \\
\hline V17 & right & 1.12 & 14 & 10 & 90 & 10 & 2.1 & 9.9 & 8.5 & 8.0 & 7.0 & $40.5(\mathrm{VH})$ \\
\hline V18 & left & 1.16 & 16 & 10 & 90 & 10 & 3.7 & 7.9 & 8.5 & 8.0 & 7.0 & $45.1(\mathrm{VH})$ \\
\hline V19 & right & 2.00 & 10 & 5 & 90 & 10 & 7.9 & 9.5 & 9.0 & 8.0 & 7.0 & $46.4(\mathrm{VH})$ \\
\hline V20 & right & 1.06 & 38 & 30 & 70 & 25 & 1.6 & 4.8 & 6.0 & 5.0 & 6.5 & $33.9(\mathrm{H})$ \\
\hline
\end{tabular}

For location see Fig. $1, M=$ moderate, $H=H i g h, V H=$ very high 

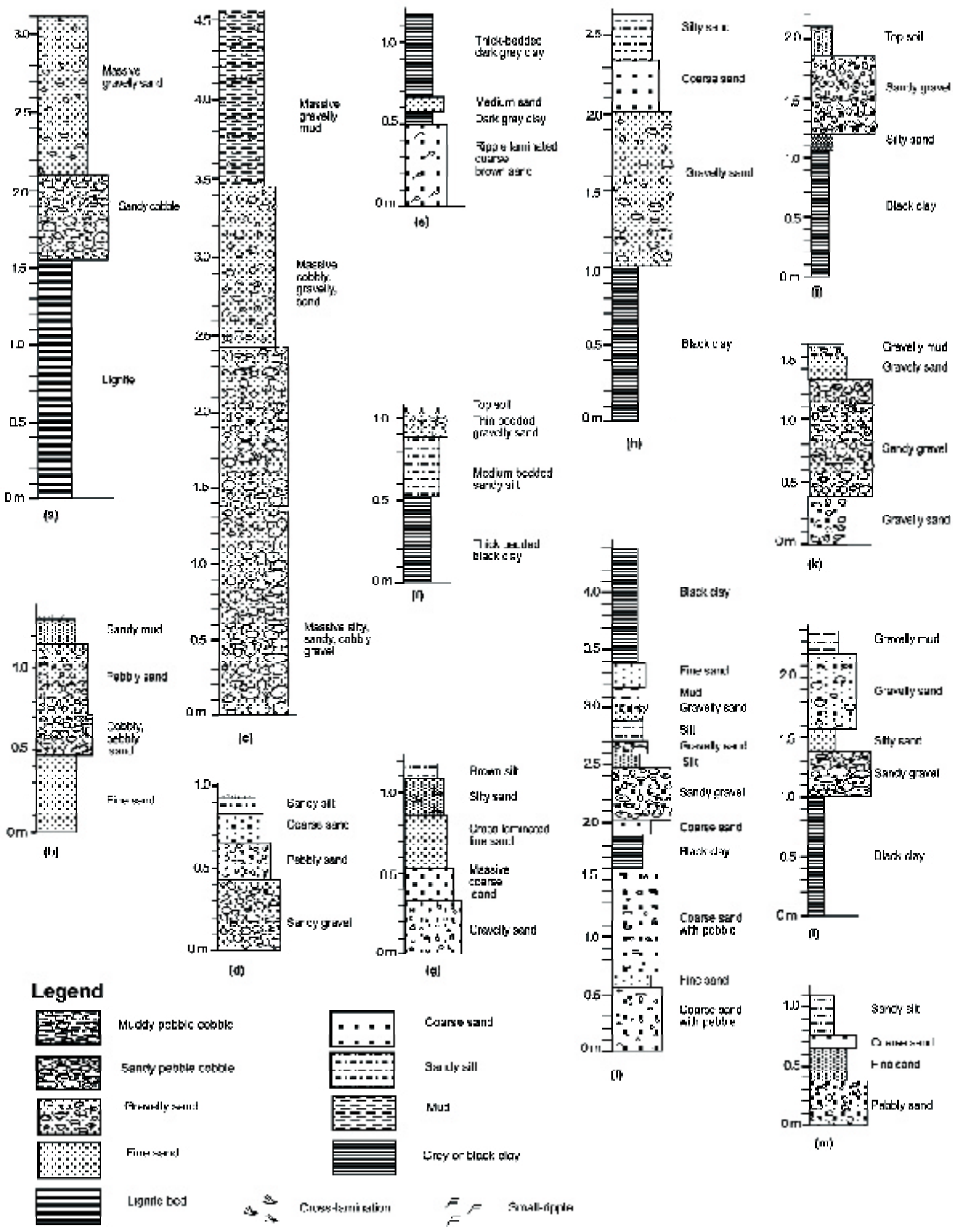

$\{k \hat{\jmath}$
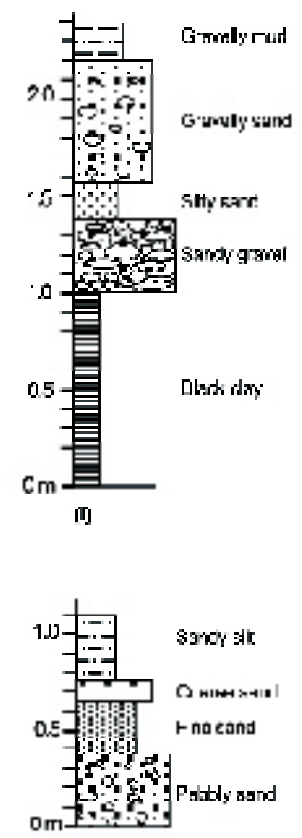

(m)

Fig. 6: Lithologs of bank materials in the Manahara River at (a) V2 (see Fig. 1 for location), near Sankhu; (b) V3, near Salambutar; (c) V5, near Salambutar; (d) V7, near Kurthali; (e) V11, near Mulpani; (f) V12, near Mulpani; (g) V14, near Somathali; (h) V15, near Somathali; (i) V16, near Bodegaun; (j) V17, near Bodegaun; (k) V18, near Magargaun; (l) V19, near Magargaun; and (m) V20, near SanoThimi 

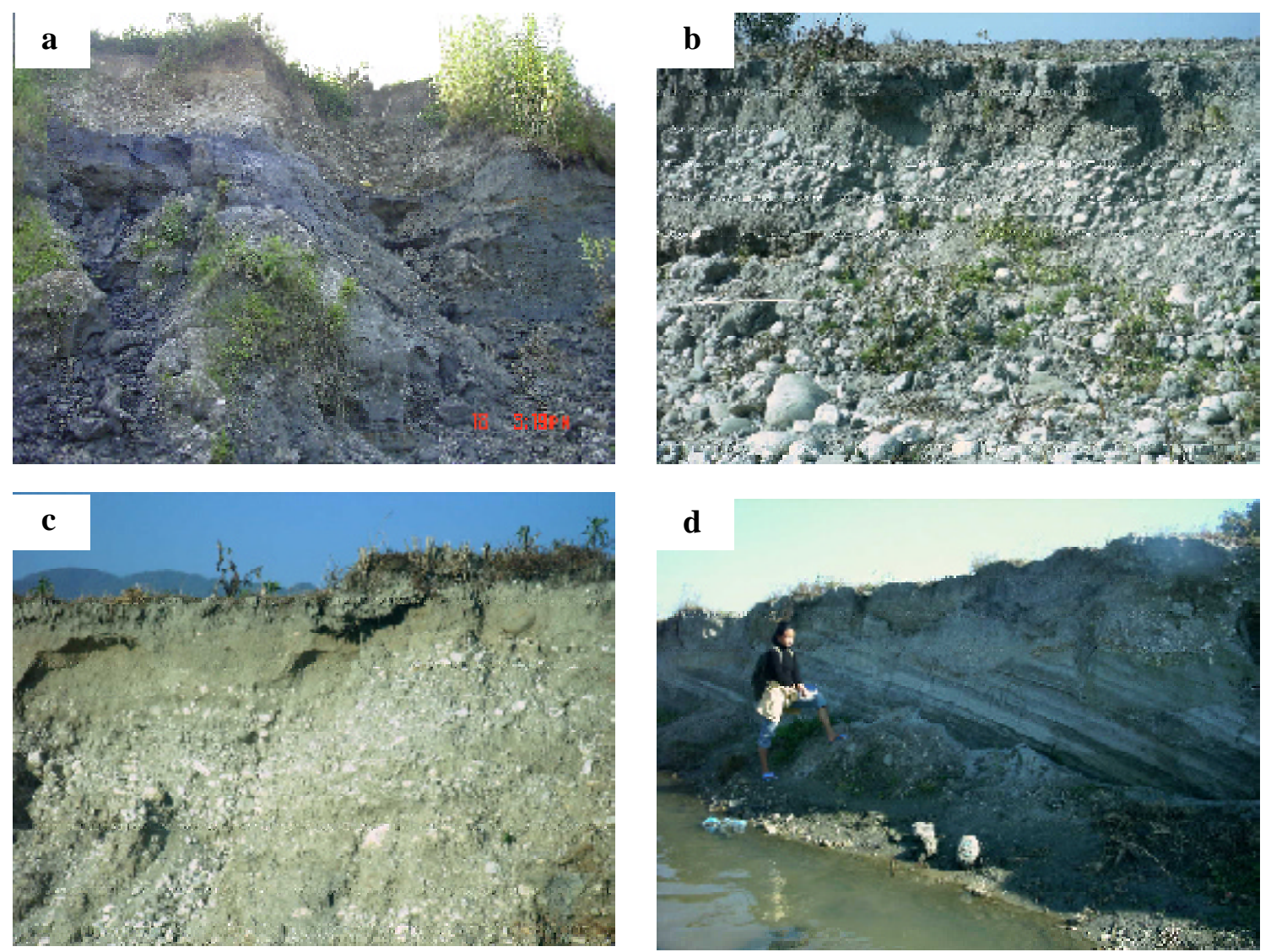

Fig. 7: Photographs showing (a) gully erosion on sandy cobbles and gravelly sand at Sankhu, (b) riverbank at Salambutar composed of sandy cobbles and thin vegetation cover at Salambutar, (c) sandy gravel and gravelly sand in the riverbank at Kurthali, and (d) Inclinded strata of clay and silt (i.e. Thimi Formation) at Sano Thimi overlain by sandy gravel of the Manahara River

Unconsolidated and cohesionless bank material distributed in most of the places of the river offer low resistance to shearing force of stream. Poor riparian vegetation seems to be one of the influencing factors aggravating bank erodibility hazard in the river. Low root depth ratio and low root density greatly increase BEHI. The canopy cover (overstorey and understorey) distributed in the fourth-order stretches is good in terms of bank material protection from the erosion as the root depth of these vegetation exceeds $1 \mathrm{~m}$ and the root network also supports sediment. Because understorey and ground cover mostly represent the riparian vegetation of the fifth-order main stem, the roots hardly exceeds $1 \mathrm{~m}$ in length and their network supports only the upper few centimetres of soil. Therefore such vegetation is not strong enough to protect the banks. However, the vegetation helps to prevent sheet erosion and raindrop impact.

\section{Near-bank stress index}

Each streamwidth at a selected locality was divided into three equal parts to find the shear stress in the near-bank region as compared to the bankfull tractive shear stress of the entire channel. The depth and slope of near-bank region were taken for estimating the near-bank shear stress (Rosgen 2001):

$$
\tau_{\mathrm{nb}}=\gamma \mathrm{d}_{\mathrm{nb}} \cdot \mathrm{S}_{\mathrm{nb}}
$$

where $\tau_{\mathrm{nb}}=$ near-bank shear stress $\left(\mathrm{kN} / \mathrm{m}^{2}\right), \gamma=$ unit weight of water $\left(\mathrm{kN} / \mathrm{m}^{3}\right), \mathrm{d}_{\mathrm{nb}}=$ near-bank maximum depth $(\mathrm{m})$, and $\mathrm{S}_{\mathrm{nb}}=$ near bank stream slope $(\mathrm{m} / \mathrm{m})$.

Tractive shear stress $\tau$ was obtained using the following expression of Shield's (1936):

$$
\tau=\gamma \mathrm{RS}
$$

Then, NBSI (ratio of $\tau_{\mathrm{nb}}$ to $\tau$ ) was calculated. The values of NBSI were then converted to a hazard rating system (Fig. 4, Table 1). If the near-bank shear stress is greater than the tractive shear stress, the flowing river water is capable of eroding the banks.

\section{Status of near-bank shear stress}

Almost all the locations (except V1) exhibit very high to extreme near-bank shear stress hazard ratings (Table 3). The 
Table 3: NBSI values and corresponding hazard ratings

\begin{tabular}{|c|c|c|c|c|c|}
\hline Location & $\tau_{\mathbf{n b}}(\mathbf{K P a})$ & $\tau(\mathbf{K P a})$ & NBSI $=\tau_{\mathbf{n b}} / \tau$ & Rating & Hazard level \\
\hline V1 & 30.90 & 35.71 & 0.87 & 2.50 & $\mathrm{~L}$ \\
\hline $\mathrm{V} 2$ & 48.07 & 31.59 & 1.52 & 8.90 & $\mathrm{VH}$ \\
\hline V3 & 30.61 & 18.85 & 1.62 & 9.02 & $\mathrm{E}$ \\
\hline $\mathrm{V} 4$ & 34.14 & 23.47 & 1.46 & 8.80 & $\mathrm{VH}$ \\
\hline V5 & 40.02 & 22.56 & 1.77 & 9.17 & $\mathrm{E}$ \\
\hline V6 & 43.16 & 25.17 & 1.72 & 9.12 & $\mathrm{E}$ \\
\hline V7 & 23.54 & 18.98 & 1.24 & 8.28 & $\mathrm{VH}$ \\
\hline V8 & 24.53 & 20.22 & 1.21 & 8.10 & $\mathrm{VH}$ \\
\hline V9 & 38.26 & 22.42 & 1.71 & 9.10 & $\mathrm{E}$ \\
\hline $\mathrm{V} 10$ & 20.60 & 13.13 & 1.57 & 8.93 & $\mathrm{VH}$ \\
\hline V11 & 19.62 & 10.42 & 1.88 & 9.20 & $E$ \\
\hline $\mathrm{V} 12$ & 18.98 & 13.33 & 1.42 & 8.60 & $\mathrm{VH}$ \\
\hline V13 & 21.58 & 14.07 & 1.53 & 8.92 & $\mathrm{VH}$ \\
\hline V14 & 18.84 & 12.36 & 1.52 & 8.90 & $\mathrm{VH}$ \\
\hline V15 & 18.84 & 11.30 & 1.67 & 9.10 & $\mathrm{E}$ \\
\hline $\mathrm{V} 16$ & 74.46 & 48.57 & 1.53 & 8.92 & $\mathrm{VH}$ \\
\hline $\mathrm{V} 17$ & 42.87 & 39.65 & 1.08 & 4.40 & $\mathrm{M}$ \\
\hline V18 & 80.05 & 41.72 & 1.92 & 9.20 & $E$ \\
\hline V19 & 63.77 & 41.24 & 1.55 & 8.95 & $\mathrm{VH}$ \\
\hline $\mathrm{V} 20$ & 83.39 & 51.99 & 1.60 & 9.00 & $\mathrm{E}$ \\
\hline
\end{tabular}

results show that the banks of the Manahara River are subject to very high near-bank stresses. At the locations where NBSI is very high to extreme (e.g. Kurthali, Mulpani, Sano Thimi), the lateral erosion is also remarkable (Shrestha 2007).

\section{Lateral instability hazard index}

Bank erosion is directly related to stream sinuosity. Erosion is often confined to the outside edge of a meander. On the other hand, the meander belt width ratio (MWR: ratio of meander belt width to width of channel with bankfull discharge), meander length ratio (MLR: ratio of meander wavelength to width of channel with bankfull discharge) and width depth ratio (W/D: ratio of the channel with bankfull discharge to the mean depth of bankfull stream) of the river also influence the lateral instability of a river, as laterally unstable rivers usually have higher values of above indices. MWR and MLR indicate lateral containment of the river. W/D ratio indicates instability, as an increased W/D ratio is often associated with bank erosion and channel widening. Lateral instability hazard indices of all study sites were calculated using Table 1 and Fig. 5 from the planiform and cross-section survey results.

\section{Status of lateral instability hazard}

The results of lateral instability hazard are indicated in Table 4. Except for one location (V13), LIHI ranges from moderate to high. Very high LIHI is due to high values of almost all the planiform parameters. MWR and K largely influence the hazard rating, as increased MWR and K increase LIHI.

LIHI is moderate to high. MWR, MLR and sinuosity influence LIHI, and increase in these attributes tends to increase LIHI. Such planiform parameters are often subjected to change with time due to adjustment in river caused by basin-wide land use change and sediment yield and a longterm variation in discharge.

\section{Anthropogenic disturbances}

Natural as well as anthropogenic factors are responsible for contributing to bank erosion hazard in a river. Bank encroachment, mining of construction materials from channel and bank, and cultivation on banks are the major anthropogenic activities contributing to bank erosion. Per cent disturbances were assessed qualitatively (using Table 1) in the study site to give ratings from 1 to 10 into six hazard categories from very low to extreme.

\section{Status of anthropogenic disturbances}

The inhabitants have encroached on the streambanks and bars of the Manahara River mainly for agricultural use and infrastructural development. The extent of anthropogenic activities affecting streambank erosion is less observed in headwaters. The forth-order stretch in Sankhu is moderately affected by human activities. In this segment, cultivation on riverbanks accelerates bank erosion. The fifthorder stretches are remarkably affected by human activities, but compared to the Bishnumati River, the disturbances observed in the Manahara River are low. The study sites located downstream of Mulpani belong to very high to extreme hazard levels. The stretches near the Mulpani and Sano Thimi areas are seriously affected by the anthropogenic disturbances, such as cultivation, disposal of sewage, and sand mining. 


\section{Pramila Shrestha and Naresh Kazi Tamrakar}

Table 4: Determination of total hazard ratings for LIHI based on river morphology and planiform geometry

\begin{tabular}{c|c|c|c|c|c|c|c|c|c|c}
\hline Location & K & Rating & MWR & Rating & MLR & Rating & W/D ratio & Rating & $\begin{array}{c}\text { Total } \\
\text { rating }\end{array}$ & $\begin{array}{c}\text { Hazard } \\
\text { level }\end{array}$ \\
\hline V1 & 1.3 & 3.4 & 14.2 & 7.7 & 25.8 & 8.15 & 28.0 & 8.6 & 27.9 & $\mathrm{H}$ \\
\hline V2 & 1.5 & 5.3 & 3.82 & 3.3 & 16.0 & 4.40 & 82.1 & 9.5 & 22.5 & $\mathrm{M}$ \\
\hline V3 & 1.4 & 4.1 & 5.19 & 4.5 & 25.2 & 8.02 & 82.1 & 9.5 & 26.1 & $\mathrm{H}$ \\
\hline V4 & 1.6 & 6.1 & 8.50 & 5.4 & 18.3 & 5.20 & 27.9 & 8.58 & 25.3 & $\mathrm{H}$ \\
\hline V5 & 1.5 & 5.2 & 6.03 & 4.4 & 9.44 & 1.75 & 74.4 & 9.45 & 20.8 & $\mathrm{M}$ \\
\hline V6 & 1.5 & 5.1 & 6.79 & 4.6 & 12.9 & 3.10 & 63.0 & 9.3 & 22.1 & $\mathrm{M}$ \\
\hline V7 & 1.7 & 6.7 & 9.26 & 5.7 & 17.4 & 4.90 & 74.2 & 9.44 & 26.7 & $\mathrm{H}$ \\
\hline V8 & 1.3 & 2.7 & 13.1 & 7.3 & 26.2 & 8.25 & 16.6 & 7.5 & 25.8 & $\mathrm{H}$ \\
\hline V9 & 1.6 & 5.5 & 14.3 & 7.7 & 32.4 & 9.25 & 16.2 & 7.42 & 29.9 & $\mathrm{H}$ \\
\hline V10 & 1.5 & 5.4 & 9.66 & 5.9 & 13.8 & 3.50 & 33.6 & 8.8 & 23.6 & $\mathrm{M}$ \\
\hline V11 & 1.8 & 8.3 & 13.3 & 7.4 & 18.5 & 5.30 & 78.4 & 9.5 & 30.5 & $\mathrm{H}$ \\
\hline V12 & 1.4 & 4.3 & 15.1 & 8.1 & 34.0 & 9.40 & 50.5 & 9.2 & 31.0 & $\mathrm{H}$ \\
\hline V13 & 3.1 & 9.8 & 21.1 & 9.2 & 19.6 & 5.82 & 75.0 & 9.46 & 34.3 & $\mathrm{VH}$ \\
\hline V14 & 1.9 & 8.5 & 5.86 & 4.3 & 7.95 & 1.15 & 95.2 & 9.6 & 23.6 & $\mathrm{M}$ \\
\hline V15 & 1.3 & 3.4 & 5.86 & 4.3 & 15.5 & 4.15 & 58.9 & 9.25 & 21.1 & $\mathrm{M}$ \\
\hline V16 & 1.5 & 4.9 & 7.66 & 5.1 & 13.2 & 3.12 & 68.1 & 9.35 & 22.5 & $\mathrm{M}$ \\
\hline V17 & 2.2 & 9.6 & 9.71 & 5.8 & 6.00 & 4.00 & 87.5 & 9.55 & 29.0 & $\mathrm{H}$ \\
\hline V18 & 1.4 & 4.4 & 8.21 & 5.4 & 7.86 & 1.10 & 69.3 & 9.38 & 20.3 & $\mathrm{M}$ \\
\hline V19 & 1.2 & 1.7 & 6.82 & 4.7 & 11.8 & 2.76 & 87.7 & 9.57 & 18.7 & $\mathrm{M}$ \\
\hline V20 & 1.2 & 2.4 & 11.6 & 6.7 & 23.2 & 7.30 & 76.2 & 9.46 & 25.9 & $\mathrm{H}$ \\
\hline Foraton & & & & & & & & \\
\hline
\end{tabular}

For location see Fig. $1, L=$ low, $M=$ medium, $V H=$ very high, $E=$ Extreme

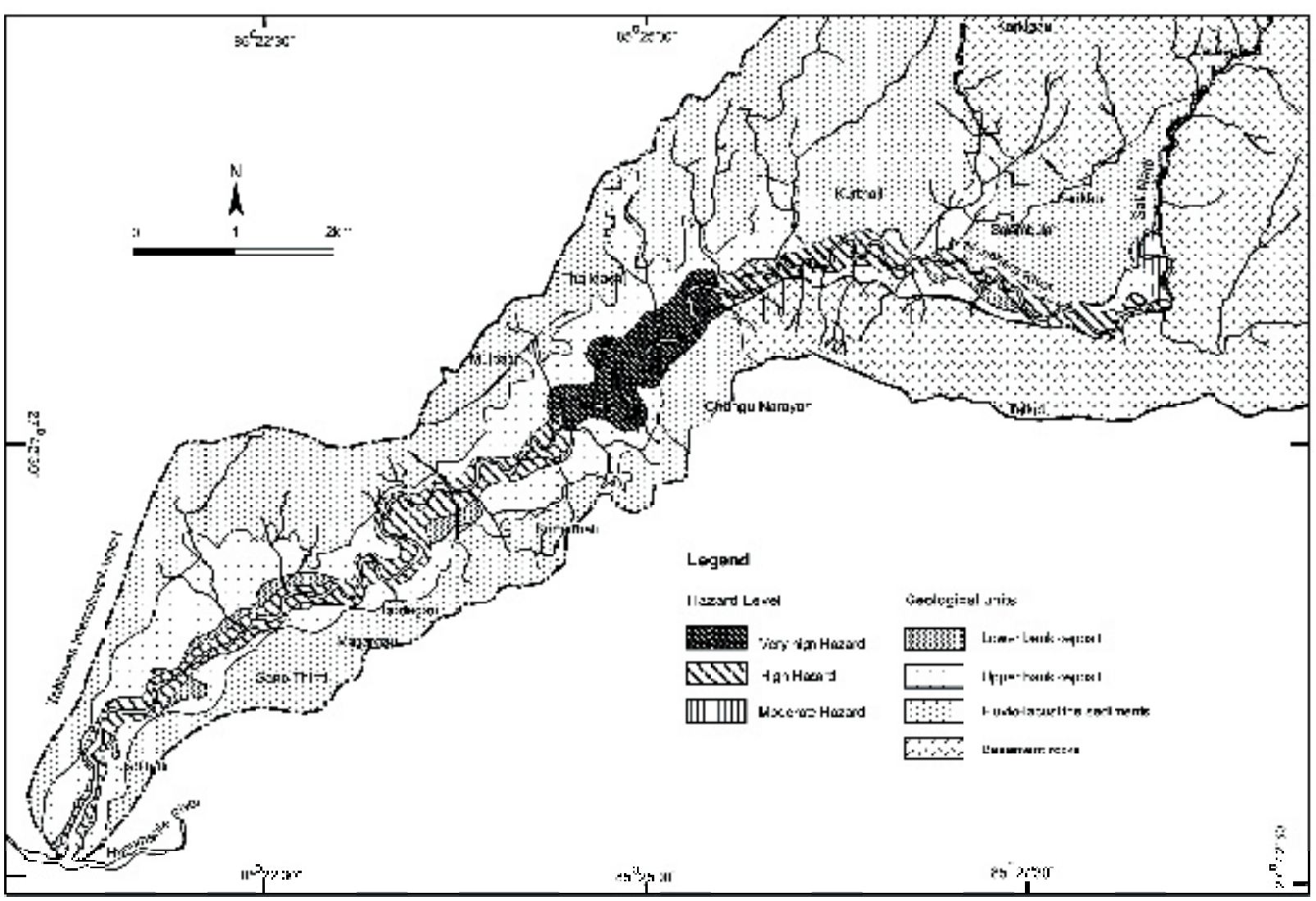

Fig. 8: Map of the Manahara River indicating BELI hazard levels 
Table 5: BELI hazard ratings and their corresponding hazard levels

\begin{tabular}{l|c|c|c|c|c|c}
\hline Location & BEHI & NBSI & LIHI & AF & Total rating & Hazard \\
\hline V1 & 24.1 & 2.50 & 27.9 & 4 & 58.5 & M \\
\hline V2 & 28.2 & 8.90 & 22.5 & 6 & 65.6 & M \\
\hline V3 & 38.6 & 9.02 & 26.1 & 8 & 81.7 & $\mathrm{H}$ \\
\hline V4 & 32.8 & 8.80 & 25.3 & 7 & 73.9 & $\mathrm{H}$ \\
\hline V5 & 41.2 & 9.17 & 20.8 & 7 & 78.2 & $\mathrm{H}$ \\
\hline V6 & 36.9 & 9.12 & 22.1 & 7 & 75.1 & $\mathrm{H}$ \\
\hline V7 & 40.9 & 8.28 & 26.7 & 7 & 82.9 & $\mathrm{H}$ \\
\hline V8 & 33.9 & 8.15 & 25.8 & 8 & 75.8 & $\mathrm{H}$ \\
\hline V9 & 27.9 & 9.10 & 29.9 & 8 & 74.9 & $\mathrm{H}$ \\
\hline V10 & 33.3 & 8.93 & 23.6 & 8 & 73.8 & $\mathrm{H}$ \\
\hline V11 & 41.7 & 9.20 & 30.5 & 8 & 89.4 & $\mathrm{VH}$ \\
\hline V12 & 41.5 & 8.60 & 31.0 & 8 & 89.1 & $\mathrm{VH}$ \\
\hline V13 & 46.4 & 8.92 & 34.3 & 8 & 97.6 & $\mathrm{VH}$ \\
\hline V14 & 32.7 & 8.90 & 23.6 & 8 & 73.2 & $\mathrm{H}$ \\
\hline V15 & 39.2 & 9.10 & 21.1 & 9 & 78.4 & $\mathrm{H}$ \\
\hline V16 & 35.6 & 8.92 & 22.5 & 9 & 76.0 & $\mathrm{H}$ \\
\hline V17 & 40.5 & 4.40 & 29.0 & 9 & 82.9 & $\mathrm{H}$ \\
\hline V18 & 45.1 & 9.20 & 20.3 & 9 & 83.6 & $\mathrm{H}$ \\
\hline V19 & 46.4 & 8.95 & 18.7 & 9 & 83.1 & $\mathrm{H}$ \\
\hline V20 & 33.9 & 9.00 & 25.9 & 9 & 77.8 & $\mathrm{H}$ \\
\hline
\end{tabular}

For location see Fig. $1, M=$ medium, $H=$ high, $V H=$ very high, $B E H I=$ bank erosion hazard index, NBSI = near bank shear stress, LIHI = lateral instability hazard index, AF = anthropoginic factor

\section{RESULTS OF BELI HAZARD}

The results obtained from the above four major parameters (i.e. BEHI, NBSI, LIHI, and AD) were combined to obtain a final BELI hazard map (Fig. 8, Table 5). It shows that the riverbanks having moderate hazard (V1 and V2) are located upstream from the confluence of the Sali Nadi and the Ghatte Khola. The riverbanks with very high hazard (V11, V12 and V13) are observed in the Mulpani area. The riverbanks from Salambutar to Kurthali and Somathali to Jadibuti are characterised by high bank erodibility and lateral instability hazards (Fig. 8).

The major causes of accelerated bank erosion in the study area are human encroachment, lack of riparian buffer zone, and loose sediments constituting the banks. Besides, neotectonics and river meander length or belt migration are the regional causes responsible for the bank erodibility and lateral instability hazard in the river.

\section{CONCLUSIONS}

The fourth-order main stem of the Manahara River falls in a moderate level of BELI hazard. A very high hazard level is observed in the river stretch near Mulpani. The rest of river stretches around Kurthali and Sano Thimi possess a high hazard level. The BELI hazard level is greatly influenced by BEHI and anthropogenic disturbances. Minimising human disturbances (prohibiting river bar cultivation, sand and gravel excavation from riverbeds, effluent discharge into river, and bank encroachments) is a way to minimise the hazard level, but it is not enough. One of the most effective ways to reduce the hazard is to establish riparian vegetation buffer zones with diverse plant species that produce a strong root network.

\section{ACKNOWLEDGEMENTS}

Authors are thankful to Mr. P. C. Adhikary, Central Department of Geology for providing facilities of survey instruments. Authors thank Ms. R. Bajracharya and Mr. S. Maharjan for their assistance during surveys and Mr. A. Pradhan for reproducing some graphics.

\section{REFERENCES}

Adhikari, B. R. and Tamrakar, N. K., 2007, Bank instability and erosion problems of Bishnumati River, Kathmandu, Nepal. Proceeding of $5^{\text {th }}$ conference of International Association of Engineering Geologists, Jour. Nepal Geol. Soc., Sp. Issue, v. 32, 37-38 pp.

Bajracharya, K. R., 2001, Geology of Bhaktapur-Nagarkot area. Unpublished M. Sc. Thesis submitted to Central Department of Geology, Tribhuvan University, Kathmandu, Nepal, 76p.

Bajracharya, R., 2006, Study of geoenvironmental problems of the Manohara River, Kathmandu, Nepal. Unpublished M. Sc. Thesis submitted to Central Department of Geology, Tribhuvan University, Kathmandu, Nepal, 132 p. 
Bajracharya, S. R., 1992, Fluvial system of Kathmandu valley in relation to neotectonics. Bulletin of Department of Geology, Tribhuvan University, Kathmandu, v. 2(1), pp. 173-179.

DHM, 2005, Hydrological records of Nepal, Kathmandu, Department of Hydrology and Meteorology (DHM), Ministry of water resources, HMG, Nepal.

Leopold, L. B. and Wolman, M. G., 1960, River meanders. Geological Society of America Bulletin, v. 71, pp. 769-794.

Ohta, Y., 1973, Geology of the Nepal Himalayas, In: K. Arita, Y. Ohta, C. Akiba and Y. Mauro, (Eds.), Geology of Himalayas. Saikon Publication Co. Ltd., pp. 235-259.

Rosgen, D. L., 1976, The use of colour infrared photography for the determination of suspended sediment concentrations and source areas. In: proceedings of the third inter-agency sediment conference, Water Resources Council. 30-42 pp.

Rosgen, D. L., 1994, A classification of natural rivers, Cantenna, v. 22, pp. 169-199.

Rosgen, D. L., 1996, Applied river morphology, Wildland Hydrology, Pasoga, Springs, Colorado, 390 p.

Rosgen, D. L., 2001, A stream channel stability assessment methodology. In Proceedings of the Seventh International Sedimentation Conference, Reno, Nevada, March, pp. 25-28.
Sakai, H., Fujii, R., and Kuwahara, Y., 2002, Changes in depositional system of the Palaeo-Kathmandu Lake caused by upliftment of the Nepal Lesser Himalayas. Jour. Asian Earth Sci., v. 20, pp 217-224.

Shields, A., 1936, Application of similarity principles and turbulence research to bed-load movement. In: W. P. Ott and J. C. Uchelen (translators), Mitt. Preuss. Verschsanst., Berlin. Wasserbau Schiffbau. California Institute of Technology, Pasadena. CA, Report No. 167, 43 p.

Shrestha, P., 2007, Streambank condition, erosion process and bank erodibility and lateral instability hazard along the Manahara River with reference to bank erosion hazard mapping. Unpublished M. Sc. Thesis submitted to Central Department of Geology, Tribhuvan University, Kathmandu, Nepal, 188 p.

Stöcklin, J. and Bhattarai, K. D., 1977, Geology of the Kathmandu area and Central Mahabharat range, Nepal Himalaya. Report of Department of Mines and Geology/UNDP (unpublished report), $86 \mathrm{p}$.

Tamrakar, N. K., 2004, Disturbances and instabilities in the Bishnumati River corridor, Kathmandu basin, JUSAN, v. 9(16), pp. 7-18. 